\title{
A Macro Political Examination of the Partisan and Ideological Divide in Aggregate Public Concern over Climate Change in the U.S. between 2001 and 2013
}

\author{
Joanna K. Huxster (Corresponding author) \\ Department of Sociology, Drexel University, Philadelphia, PA United States \\ E-mail: jkh49@drexel.edu \\ Jason T. Carmichael \\ Department of Sociology, McGill University, Montreal, Canada \\ E-mail: Jason.carmichael@mcgill.ca
}

Robert J. Brulle

Department of Sociology, Drexel University, Philadelphia, PA United States

E-mail: rbrulle@gmail.com

Received: November 1, 2014 Accepted: November 24, 2014

doi:10.5296/emsd.v4i1.6531 URL: http://dx.doi.org/10.5296/emsd.v4i1.6531

\begin{abstract}
Recent individual level analyses have detailed a progressive polarization between political parties in public concern and understanding of climate change. These micro political analyses are limited by the data and time-scale available in the use of a single surveying organization and instrument. In this paper, we employ macro political analysis of all relevant polling data available on the Roper iPoll Database to develop reliable and valid measures of aggregate public concern over the issue of climate change across a 13-year time-period. Aggregate public opinion is analyzed and separated by political ideology and party identification using Stimson's (1999) method for pooling multiple polls. Through statistical analysis of six measures of aggregate public opinion trends, we find significant differences between trends in public concern across political and ideological lines, and find that the political right and political left
\end{abstract}


have not only become more polarized on the issue of climate change between 2001 and 2013, but that the populations are not moving as parallel publics as previous literature suggests they might.

Keywords: Climate change, Public opinion, Political polarization

\section{Introduction}

Individual-level analyses have detailed a progressive polarization between political parties in public concern about climate change (Guber 2013, McCright 2011), but these analyses are often plagued by limitations in the availability of repeated survey items that track this issue over time. We have overcome previous limitations by developing separate quarterly measures of concern over global climate change by both party affiliation and political ideology utilizing Stimson's method of constructing aggregate public opinion measures (Stimson 1999). This aggregate measure of climate change concern is based on data from 69 surveys administered between 2001 and 2013. These measures present us with a significant divide between the political right and the political left. We also show that polarization in climate change concern has grown over the 13-year time period, and that these populations are not moving as "parallel publics" as previous literature suggests (Kellstedt 2003, Enns and Kellstedt 2008).

In a 2014 Gallup Poll, 83\% of Democrats and only 38\% of Republicans expressed concern over climate change, and several individual-level analyses detailed this progressive polarization (Guber 2013, McCright 2011, Krosnick et al 2006). There is, however, a great deal of variation in the data collected at the individual-level. For example, in Pew Research Center's 2014 report, $50 \%$ of Republicans indicated concern over climate change, with Democrats at $81 \%$. While there has been some important work in this area, the existing analyses are limited in time-scale, to a single data source, and by question wording. McCright and Dunlap (2011) for instance, report an increase in political polarization on the subject of climate change but their study uses only annual data and relies exclusively on questions derived from Gallup polls. Guber (2013) also finds a polarization in climate change concern, but her analyses only examine changes across three cross-sectional polls administered at 10-year intervals, again drawing only from Gallup. While these individual-level studies do help identify the polarized nature of the debate about climate change, the data limitations from which they suffer beg for a more robust examination.

To remedy this problem, we utilize the "policy mood" approach developed by James Stimson to construct six separate climate change indices. With these indices, we present a robust indicator of the quarterly shifts in climate change concern between 2001 and 2013, disaggregated by party affiliation and political ideology, as well as for the overall population. Unlike prior studies in this area, this approach will allow us to incorporate all of the available U.S. national public opinion polls on climate change rather than relying on just one poll or organization. We compare these groups, and conclude with observations on the utility of these measures and areas for future research. This type of aggregation allows us to tell a more complete story than do individual-source analyses, by including a diverse set of survey items on climate change concern derived from multiple polling organizations, with questions administered multiple times per year. 


\subsection{Macro Politics and Aggregate Analysis}

There are two different approaches to the measurement of public opinion. The first and most common is the analysis of micro politics. Based in psychology, this approach analyzes the individual-level characteristics that produce variations in specific attitudes, beliefs, and behaviors through the use of survey research. The second approach to the study of public opinion is known as macro politics. Instead of focusing on the individual, the unit of analysis is public opinion data aggregated to some larger unit (typically, the entire country). This approach focuses on the structural conditions that may drive changes in aggregate public opinion over time (Erikson et al 2002, Stimson 2004). Given that this research aims to study macro-level phenomenon and the movement of U.S. public concern over climate change across time, a macro political approach is more appropriate for this analysis (Keele 2007).

Periodic surveys of public opinion related to climate change have very recently been developed ${ }^{1}$, but many years will pass before these measures provide sufficient cases to estimate shifts using time-series techniques. In addition, these surveys will do little to capture data from the past due to inconsistencies in question wording and survey administration. In 2012, Brulle et al developed the first valid trend measure of this subject, the Climate Change Threat Index (CCTI), for the years 2002 through 2010 using Stimson's "Policy Mood" analysis (Brulle 2012, Stimson 1999). In his research, Stimson developed an algorithm to measure "policy moods" over time by using all existing survey data related to a particular social issue to construct a longitudinal index of public opinion.

Stimson's "Policy Mood" analysis and algorithm have been effectively applied to a number of topics in sociology and political science (Kellstedt 2003, Kellstedt et al 2008, Brulle 2013, Ramirez 2013, Krosnick 2006). There are several advantages of this aggregate approach over individual-level analyses. By developing an aggregate "Policy Mood", the Stimson algorithm can provide more accurate measures of issue or policy concern because it can utilize all the available survey data about a particular subject. The use of an algorithm to mathematically standardize data across multiple polling organizations has the advantage of minimizing the influence of researcher discretion in their specific survey item selection, and allows the measure to be invariant with respect to differences in question wording across polling organizations (Stimson 1999). A more complete explanation of Stimson's methodology and algorithm can be found in the Methods section of this paper.

\subsection{Parallel Publics}

The literature on aggregate public opinion measures posits that "parallel publics" exist, and that for some portions of the public, opinion is stable and fixed mainly by social and ideological identities (Enns and Kellstedt 2008, Brulle 2012, Kellstedt 2010). However, micro-political literature also shows a widening partisan divide on the issue of climate change, which indicates that individuals may be responding differently to media coverage and political cues depending on their own political beliefs. Furthermore, recent studies show that

\footnotetext{
${ }^{1}$ See the Six Americas Project at the George Mason University Center for Climate Change Communication (http://www.climatechangecommunication.org/) and the work of Jon Krosnick (http://climatepublicopinion.stanford.edu/).
} 
self-identified liberals and democrats are more likely than political conservatives to report beliefs consistent with the scientific consensus about climate change (IPCC 2013), and that the ideological and partisan gap in climate change beliefs has increased significantly between 2001 and 2010 (Guber 2013, McCright 2011). A macro-political approach to this question, which has not been explored prior to this study, will allow for the testing of the existence of "parallel publics" on this subject.

Building on this literature, we seek to use a more robust, aggregate-level analysis to ask the following questions: 1) Does the gap in concern over climate change between Republican and Democrats (or Conservatives and Liberals) increase between 2001 and 2013?; and 2) Do the ideological and partisan groups move as "parallel publics" in their climate change concern over this 13-year time period? We answer these questions using Stimson's algorithm to calculate a public mood using all available polling data since 2001. Doing so will help improve our understanding of the ideological divide in climate change beliefs by applying a more vigorous and reliable measure of public opinion.

\section{Methods}

In applying Stimson's methodology, survey marginals for responses of interest are compiled from all relevant questions, making each nationwide survey a single data point. These data points can then be analyzed over time, using Stimson's algorithm. ${ }^{8}$ The algorithm examines the relationship between the marginals, and places each survey on a common metric of ratios by comparing the survey marginal for a question with itself across time. The algorithm then averages the questions across question and time using backward and forward recursion, filling in missing data along the way (Kellstedt 2010). This develops a measure of central tendency, creating a comparable metric for each survey question. The resulting variations in the metric are used to measure the "policy mood." One important advantage of this methodology is that existing data can be used to calculate any missing data, for example, in a year in which no survey was asked during a particular quarter. This aspect of the methodology solves a historical problem in measuring public opinion over time with traditional social research methodologies.

To measure and examine public opinion on climate change we constructed several time-series using data drawn from the Roper Center iPoll database. The database was searched for poll questions containing the words "climate change" or "global warming" and questions were selected from the search results that asked respondents to assess the level of threat they perceive from climate change. Our search identified 20 different questions from 8 different polling organizations that asked about climate change. For the majority of these polls, respondents were asked to indicate their political ideology and/or their party affiliation. Using this political identification data, combined with questions related to climate change, we were able to calculate both an Ideology Climate Change Threat Index (ICCTI) and a Party Climate Change threat Index (PCCTI). ${ }^{2}$

Between 2001 and 2013, the ICCTI included 65 surveys, which were administered to 88,711

\footnotetext{
${ }^{2}$ In ideological identification questions where respondents were given a choice between extreme and average ideology (e.g. very liberal and liberal), the two choices were combined.
} 
respondents, and the PCCTI included 69 surveys, administered to 95,981 respondents ${ }^{3}$. The inclusion of these survey questions creates a comprehensive and robust sample of all climate change surveys conducted in the United States. A list of the specific questions, dates administered, survey marginals, and polling organizations can be found in Table S1, and the variable loadings for the commonality estimates can be seen in Table S3, both in the supplementary material accompanying this article online. The method of data collection for each survey variable was consistent across all of the administrations, insuring the comparability of the survey marginals across the time period ${ }^{4}$. The survey marginal scores were processed through Stimson's algorithm using the WCALC program ${ }^{5}$ to calculate the ICCTI and PCCTI on a quarterly basis. For the ICCTI this included three indices for conservatives, liberals, and all respondents. For the PCCTI the three indices were for Republicans, Democrats, and all respondents. Using these separate series, we are able to make meaningful comparisons about public concern over climate change separated by political identification between 2001 and 2013.

The distribution of the surveys including climate change concern questions used for the PCCTI and ICCTI are shown in Table S2 in the online supplementary material. It should be noted that in 2004, only three questions were available from the database, and these were all asked in the first quarter of the year. The data from the other three quarters are interpolated by averaging survey marginals from the first quarter of 2004 and from the first quarter of 2005. The use of the Stimson algorithm allows for this missing data to be interpolated and filled in, but it should be noted that the measurement is not as robust for 2004 as it is in other years.

A two-tailed, Pearson correlation was performed to determine whether the ICCTI and the PCCTI were comparable given the small differences in the included survey administrations (Table 2). We find that the PCCTI and ICCTI were highly correlated with an $r$ value of .990, and a significance at of $p<.001$.

\section{Results}

A longitudinal measure of public climate change concern was constructed by applying the Stimson algorithm to the polling data drawn from the Roper iPoll database. The demographic data from these surveys was used to create two indices for all respondents (PCCTI and ICCTI) 6 , and one index each for Republicans, Democrats, conservatives, and liberals. Descriptive statistics for the indices are shown in Table 1 and the graphed indices over the 13 -year time period can be seen in Figure 1.

Table 1 and Figure 1 show distinct separation between the political left (Democrats and liberals) and the political right (Republicans and conservatives) in the mean aggregate scores and the trend across the time series. The significance between the two political and ideological

\footnotetext{
3 The ICCTI only includes 65 of the 69 surveys because five of the surveys did not ask respondents about their ideological positions.

${ }^{4}$ All of the polling organizations except for Yale/George Mason used telephone surveys for each administration of their survey. Yale/George Mason administered all of the variables included in this study online.

5 The WCALC program is available online at $h \mathrm{ttp}: / / \mathrm{www} . \mathrm{unc}$.edu/ jstimson/

${ }^{6}$ Two separate indices were created for party identification (PCCTI) and political ideology (ICCTI) because 4 of the surveys did not ask respondents about their ideological identification
} 


\section{Macrothink}

Environmental Management and Sustainable Development

ISSN 2164-7682 2015, Vol. 4, No. 1

extremes, and the apparent increase in the gap between these extremes, are analyzed below to answer the research questions.

With the comparability of the PCCTI and ICCTI established in the Methods section, Pearson correlations were run between all of the indices (Table 2). The results show that the liberal and Democratic indices vary together $(r=.876, p<.001)$, as do the conservative and Republican indices $(r=.905, p<.001)$. It appears that public concern about climate change is not influenced by whether one measures climate change 'mood' by party or by political ideology. There is, however, a sizable difference (Figure 1) between the political left and political right in their climate change concern. The correlations presented in Table 2 show that a statistically significant difference in climate change concern exists between Republicans and Democrats $(.083, p>.05)$ and between conservatives and liberals $(r=.055, \mathrm{p}>.05)$. When we compile all available polling data since 2001 , it is clear that climate change has been exceptionally polarized for both party affiliation and political ideology.

Table 1. Descriptive statistics for the U.S. climate change threat indices based on party affiliation and political ideology.

\begin{tabular}{|l|c|c|c|c|}
\hline & Minimum & Maximum & Mean & Std. Deviation \\
\hline Overall PCCTI & 40.03 & 54.46 & 45.61 & 4.13 \\
\hline Republicans & 18.84 & 34.04 & 25.31 & 3.76 \\
\hline Democrats & 52.25 & 69.46 & 59.38 & 4.98 \\
\hline Overall ICCTI & 40.31 & 53.27 & 45.27 & 3.81 \\
\hline Conservatives & 22.15 & 40.33 & 30.53 & 4.27 \\
\hline Liberals & 54.49 & 69.30 & 60.70 & 4.82 \\
\hline
\end{tabular}

Table 2. Pearson correlations

\begin{tabular}{|l|c|c|c|c|c|c|}
\hline & PCCTI & Reps & Dems & ICCTI & Cons & Libs \\
\hline Overall PCCTI & - & $.603 * *$ & $.739 * *$ & $.990 * *$ & $.662 * *$ & $.708^{* *}$ \\
\hline Republicans & - & - & .083 & $.616^{* *}$ & $.905^{* *}$ & .001 \\
\hline Democrats & - & - & - & $.735^{* *}$ & .179 & $.876^{* *}$ \\
\hline Overall ICCTI & - & - & - & - & $.662 * *$ & $.702 * *$ \\
\hline Conservatives & - & - & - & - & - & .055 \\
\hline Liberals & - & - & - & - & - & - \\
\hline
\end{tabular}

$* * \mathrm{p}<.001$ (two-tailed). Correlations of interest for addressing research questions in bold. 


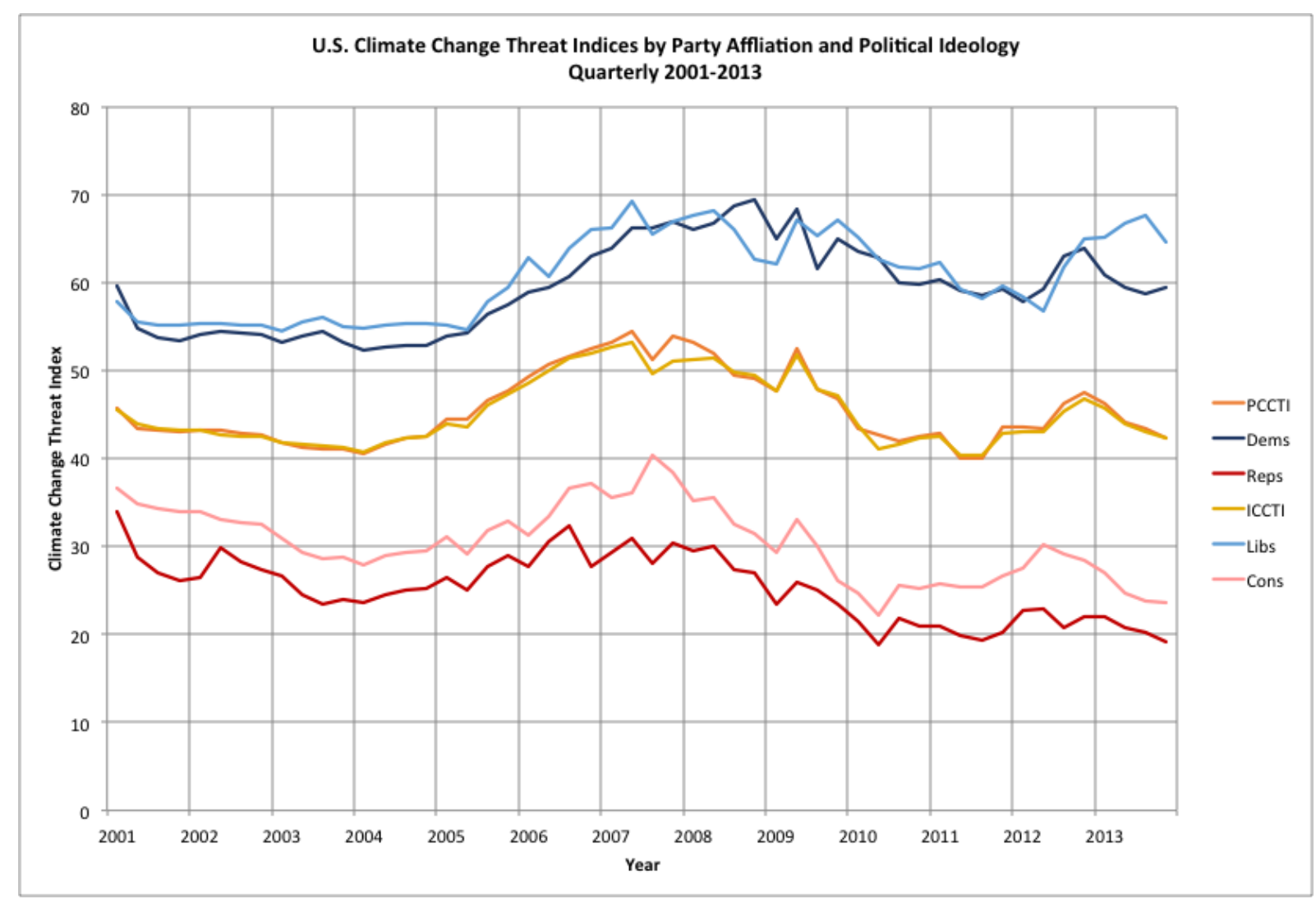

Figure 1. U.S. climate change threat indices based on party affiliation and political ideology, quarterly from 2001 to 2013.

To further analyze the relationship between the political right and the political left, we calculate a set of gap scores indicating the difference between our CCTI scores for party and ideology. Figure 2 shows partisan and ideological gaps for the climate change threat indices across the time period. A larger gap between groups suggest a greater divide in concern on the issue of climate change, while smaller gap numbers suggest that the groups are closer in opinion. We see from Figure 2 that the gap in 2013 was twice that of 2001, indicating that climate change concern has grown substantially more politically polarized. Also, we see that the gap between Republicans and Democrats is consistently higher than it is between liberals and conservatives

To test the difference in the movements of the indices, and determine whether these groups move in parallel, several statistical analyses were employed. Tests of the difference of means reveal that the CCTI for Liberals, $M_{\text {liberals }}=60.70$, is higher than the average concern amongst Conservatives, $M_{\text {conservative }}=30.52(t=34.78, p<.001)$. A similarly significant gap also exists between Democrats and Republicans. Descriptive statistics also reveal that those on the right of the political spectrum appear to be more willing than those on the left to change their position over time about climate change. Specifically, the range of movement for Conservatives (18.2) is larger than the range for Liberals (14.8).

While a substantial gaps can be seen in Figure 2 between the positions of those on the political left and those on the political right, we must rely on statistical evidence to determine whether or not these separate trends move in parallel. A simple $t$-test reveals that the mean gaps between 


\section{Macrothink}

political parties and between the political ideologies are statistically significant in each year from 2001 through 2013 (in each year the gap was significant at the $\mathrm{p}<.001$ level or greater).

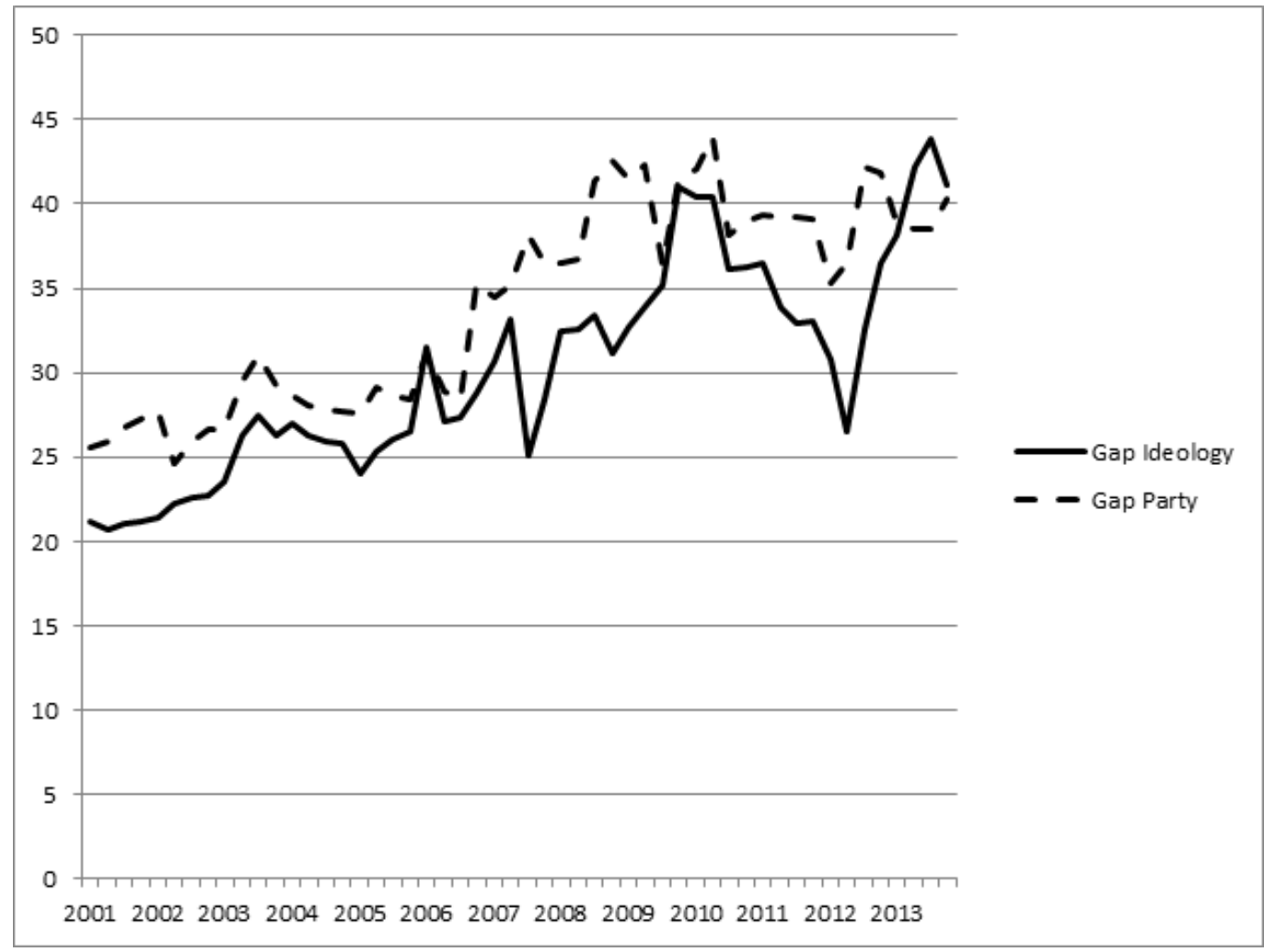

Figure 2. Gaps in the U.S. climate change threat indices based on party affiliation and political ideology, quarterly from 2001 to 2013.

\section{Discussion and Conclusion}

Utilizing Stimson's algorithm and "policy mood" technique, we find that individuals on the political left and the political right had significantly different levels of concern for climate change between 2001 and 2013, and that the polarization between these two groups has increased over this time period. In particular, the mood measure of the political right dropped by nearly half between 2007 and 2010. Since 2006, Liberals and Democrats showed more concerned, while Republicans and conservatives were less concerned in 2013 than they have been since the beginning of our time-series. Our findings of a growing partisan and ideological divide in public climate change concern are further supported by simple calculations of the gap, or the difference between partisan and ideological average threat index scores. The increase in the partisan gap between 2001 and 2013 supports the assertions about the polarization of the climate debate made in much of the recent literature, but does so using a more appropriate and methodologically stronger, aggregate-level approach (Guber 2013, McCright 2011, Brulle 2012, Kellstedt et al 2008).

Several statistic analyses were employed to determine whether or not the political left and the political right move in parallel for these measures. We find a significant gap between the political left and the political right in the difference of mean, a difference in the range of motion in public concern, and statistically significant mean gaps in each year of the study. These 
findings challenge arguments made in previous literature in which aggregate opinion measures from subsets of the population move in parallel across groups (Kellstedt 2003, Enns and Kellstedt 2008, Kellstedt et al 2008). Our findings indicate that for climate change concern across party lines, this does not hold true.

Using Stimson's "policy mood" technique allowed for the inclusion of more survey data, from a more diverse set of polling organizations than previous scholarship has been able to utilize without such an approach. Our more robust mood measure disaggregated by the political right and left allowed us to precisely track the increase in polarization on this issue. We also found that climate change concern over time moves independently between the political right and the political left. Future scholarship should work to reveal what factors influence the concern of the different, politically divided populations, and to uncover ways of moving the public past the partisan sorting and the resulting stalemate on climate change in the U.S.

\section{Acknowledgement}

We thank the Gallup organization and the Pew Research Center for their assistance in obtaining additional demographic data not available on the Roper iPoll database.

\section{References}

Brulle, R. J., Carmichael, J., \& Jenkins, J. C. (2012). Shifting public opinion on climate change: an empirical assessment of factors influencing concern over climate change in the US, 2002-2010. Climatic Change, 114, 169-188. http://dx.doi.org/ 10.1007/s10584-012-0403-y

Enns P. K., \& Kellstedt P. (2008). Policy mood and political sophistication: why everybody moves mood. British Journal of Political Science, 38, 433-454. http://dx.doi.org/10.1017/S0007123408000227

Erikson, Robert S., Mackuen Michael B., \& Stimson, James A. (2002). The Macro Polity. New York: Cambridge University Press.

Guber, Deborah Lynn. (2013). A Cooling Climate for Change? Party Polarization and the Politics of Global Warming. American Behavioral Scientist, 57(1), 93-115. http://dx.doi.org/ $10.1177 / 0002764212463361$

Intergovernmental Panel on Climate Change. (2013). IPCC Fifth Assessment Report. Geneva, Switzerland: IPCC. Available: http://www.ipcc.ch

Keele, Luke. (2007). Social Capital and the Dynamics of Trust in Government. American Journal of Political Science, 241-254. http://dx.doi.org/10.1111/j.1540-5907.2007.00248.x

Kellstedt et al. (2010). The Macro Politics of Gender Gap. Public Opinion Quarterly, 74(3), 477-498. http://dx.doi.org/10.1093/poq/nfq003

Kellstedt P. M. (2003). The mass media and the dynamics of American racial attitudes. New York: Cambridge University Press. http://dx.doi.org/10.1017/CBO9780511615634

Kellstedt P. M., Zahran P. S., \& Vedlitz A. (2008). Personal efficacy, the information 


\section{Macrothink}

environment, and attitudes toward global warming and climate change in the United States. Risk Analysis, 28(1), 113-126. http://dx.doi.org/10.1111/j.1539-6924.2008.01010.x.

Krosnick J., Holbrook A., Lowe L., \& Visser, P. (2006). The origins and consequences of democratic citizens' policy agendas: a study of popular concern about global warming. Climatic Change, 77, 7-43. http://dx.dox.org/ 10.1007/s10584-006-9068-8

McCright, A. M., \& Dunlap, R. E. (2011). The politicization of climate change and polarization in the American public's views of global warming, 2001-2010. Sociological Quarterly, 52, 155-194. http://dx.doi.org/ 10.1111/j.1533-8525.2011.01198.x

Stimson J. A. (1999). Public opinion in America; moods, cycles and swings (2nd ed). Boulder: Westview Press.

Stimson J. A. (2004). Tides of consent: how public opinion shapes American politics. New York: Cambridge University Press. http://dx.doi.org/10.1017/CBO9780511791024

Ramirez, Mark. (2013). Punitive Sentiment. Criminology, 51(2), 329-364. http://dx.doi.org/10.1111/1745-9125.12007

\section{Copyright Disclaimer}

Copyright for this article is retained by the authors, with first publication rights granted to the journal.

This is an open-access article distributed under the terms and conditions of the Creative Commons Attribution license (http://creativecommons.org/licenses/by/3.0/). 


\section{Supplementary Material}

Table S1. Survey Questions used in the Partisan and Ideology Climate Change Threat Indices

\begin{tabular}{|c|c|c|c|c|}
\hline Variable Name & Dates Administered & $\begin{array}{l}\text { Survey } \\
\text { Variabl } \\
\quad \text { e }\end{array}$ & Source & $\begin{array}{l}\text { Not in } \\
\text { ICCTI }\end{array}$ \\
\hline $\begin{array}{l}\text { I'm going to read you a list of environmental problems. As I read each one, please tell } \\
\text { me if you personally worry about this problem a great deal, a fair amount, only a little, } \\
\text { or not at all. First, how much do you personally worry about...the 'greenhouse effect' } \\
\text { or global warming? }\end{array}$ & $\begin{array}{c}\text { March 2001, April 2001, } \\
\text { March 2002, March 2003, } \\
\text { March 2004, March 2006, } \\
\text { March 2007, March 2008, } \\
\text { March 2009, March 2010, } \\
\text { March 2011, March 2012, } \\
\text { March 2013 } \\
\end{array}$ & Q12 & Gallup Poll (AIPO) & \\
\hline $\begin{array}{l}\text { Do you think that global warming will pose a threat to you or your way of life in your } \\
\text { lifetime? }\end{array}$ & $\begin{array}{l}\text { March 2001, March 2002, } \\
\text { March 2006, March 2008, } \\
\text { March 2009, March 2010, } \\
\text { March 2012, March 2013 }\end{array}$ & Q38 & $\begin{array}{l}\text { Gallup/CNN/USA } \\
\text { Today Poll }\end{array}$ & \\
\hline $\begin{array}{l}\text { Thinking about what is said in the news, in your view is the seriousness of global } \\
\text { warming--generally exaggerated, generally correct, or is it generally } \\
\text { underestimated?** }\end{array}$ & $\begin{array}{l}\text { March 2001, March 2002, } \\
\text { March 2003, March 2004, } \\
\text { March 2005, March 2006, } \\
\text { March 2007, March 2008, } \\
\text { March 2009, March 2010, } \\
\text { March 2011, March 2012, } \\
\text { March } 2013 \\
\end{array}$ & Q64 & $\begin{array}{l}\text { Gallup/CNN/USA } \\
\text { Today Poll }\end{array}$ & \\
\hline $\begin{array}{l}\text { Which of the following statements reflects your view of when the effects of global } \\
\text { warming will begin to happen? They have already begun to happen. They will start } \\
\text { happening within a few years. They will start happening within your lifetime. They } \\
\text { will not happen within your lifetime, but they will affect future generations. They will } \\
\text { never happen. }\end{array}$ & $\begin{array}{l}\text { March 2001, March 2002, } \\
\text { March 2003, March 2004, } \\
\text { March 2005, March 2006, } \\
\text { March 2007, March 2008, } \\
\text { March 2009, March 2010, } \\
\text { March 2011, March 2012, } \\
\text { March } 2013\end{array}$ & Q71 & $\begin{array}{l}\text { Gallup/CNN/USA } \\
\text { Today Poll }\end{array}$ & \\
\hline $\begin{array}{l}\text { And in the next } 10 \text { years, how likely are you to be personally affected by the following } \\
\text { threat?...Very likely, somewhat likely, not too likely, not at all likely...How likely are } \\
\text { you to be personally affected by the effects of global warming? }\end{array}$ & $\begin{array}{l}\text { June 2005, June 2007, June } \\
\qquad 2008\end{array}$ & Q2 & $\begin{array}{l}\text { Transatlantic } \quad \text { Trends } \\
\text { Survey }\end{array}$ & June 2007 \\
\hline
\end{tabular}




\section{Macrothink}

Environmental Management and Sustainable Development

ISSN 2164-7682

(I am going to read you a list of possible international threats to the United States in the next 10 years. Please tell me if you think each one on the list is an extremely important threat, an important threat, or not an important threat at all.)...The effects of global warming

Do you think global warming is an environmental problem that is causing a serious impact now, or do you think global warming isn't having a serious impact?

Do you think global warming is an environmental problem that is causing a serious impact now, or do you think the impact of global warming won't happen until sometime in the future, or do you think global warming won't have a serious impact at all?

How important is the issue of global warming to you personally--extremely important, very important, somewhat important, not too important, or not at all important?

If nothing is done to reduce global warming in the future, how serious of a problem do you think it will be for the United States--very serious, somewhat serious, not so serious or not serious at all?

Scientists use the term 'global warming' to refer to the idea that the world's average temperature may be about five degrees Fahrenheit higher in 75 years than it is now. Overall, would you say that global warming would be good, bad, or neither good nor bad? If Good, ask: Would you say it would be very good or somewhat good? If Bad, ask: Would you say it would be very bad or somewhat bad? If Neither, ask: Do you lean toward thinking it would be good, lean toward thinking it would be bad, or don't you lean either way?

In your view, is global warming a very serious problem, somewhat serious, not too serious, or not a problem?

I'd like to ask you about priorities for President [Obama/Bush] and Congress this year. As I read from a list, tell me if you think each should be a top priority, important but lower priority, not too important or should it not be done.... Dealing with global warming

\begin{tabular}{|c|c|c|c|}
\hline June 2005, June 2006 & Q999 & $\begin{array}{l}\text { Transatlantic } \text { Trends } \\
\text { Survey }\end{array}$ & \\
\hline $\begin{array}{l}\text { September 2003, May 2006, } \\
\text { August 2006, January } 2007\end{array}$ & Q34 & CBS News Poll & \\
\hline $\begin{array}{c}\text { June 2001, April 2007, October } \\
\text { 2007, December 2007, } \\
\text { February 2009, April 2010, } \\
\text { August 2010, October 2010 }\end{array}$ & Q35 & $\begin{array}{l}\text { CBS News/New York } \\
\text { Times Poll }\end{array}$ & \\
\hline $\begin{array}{l}\text { March 2006, April 2007, July } \\
2008\end{array}$ & Q46 & $\begin{array}{l}\text { ABC } \\
\text { News/Time/Stanford } \\
\text { University Poll }\end{array}$ & $\begin{array}{c}\text { March } \\
2006\end{array}$ \\
\hline $\begin{array}{l}\text { March 2006, June 2007, } \\
\text { September } 2007\end{array}$ & Q47A & $\begin{array}{l}\text { ABC } \\
\text { News/Time/Stanford } \\
\text { University Poll }\end{array}$ & $\begin{array}{c}\text { March } \\
2006\end{array}$ \\
\hline April 2007, July 2008 & Q58 & $\begin{array}{l}\text { ABC } \\
\text { News/Washington } \\
\text { Post/Stanford } \\
\text { University Poll }\end{array}$ & \\
\hline $\begin{array}{c}\text { June 2006, July 2006, January } \\
\text { 2007, April 2007, April 2008, } \\
\text { April 2009, May 2009, } \\
\text { September 2009, October } \\
\text { 2010, November 2011, } \\
\text { October 2012, March } 2013\end{array}$ & Q53 & $\begin{array}{l}\text { Pew News Interest } \\
\text { Index/Believability } \\
\text { Poll }\end{array}$ & \\
\hline $\begin{array}{c}\text { January } 2007, \text { January } 2008, \\
\text { January } 2009, \text { January } 2010, \\
\text { January } 2011, \text { January } 2012, \\
\text { January } 2013\end{array}$ & Q30 & $\begin{array}{l}\text { Pew Research: Center } \\
\text { for the People and the } \\
\text { Press }\end{array}$ & \\
\hline
\end{tabular}




\section{Macrothink}

Environmental Management and Sustainable Development

ISSN 2164-7682

I'd like your opinion about some possible international concerns for the US. Do you think that...global climate change is a major threat, a minor threat or not a threat to the well being of the United States?

(As I read a list of possible long-range foreign policy goals which the United States might have, tell me how much priority you think each should be given.)...Dealing with global climate change...Do you think this should have top priority, some priority, or no priority at all?

Do you think global warming is a problem that requires immediate government action, or don't you think it requires immediate government action?

How worried are you about global warming?

Six Americas Poll - \% Concerned or Alarmed

I am going to read you a list of possible threats to the vital interests of the United States in the next 10 years. For each one, please tell me if you see this as a critical threat, an important but not critical threat, or not an important threat at all... Global warming

Is the following something that you worry about a lot, is this something you worry

about somewhat or is this something you do not worry about?...Global warming

November 2009, November 2013

October 2005, September 2008, November 2009, May 2011, November 2013

July 2006, January 2007, April 2010, October 2010

November 2008, January 2010 June 2010, May 2011 November 2011, March 2012, September 2012, April 2013

November 2008, January 2010, June 2010, May 2011,

November 2011, March 2012 September 2012, April 2013

November 2008, January 2010, June 2010, May 2011,

November 2011, March 2012, September 2012, April 2013

June 2002, June 2006

September 2006, March 2008 2015, Vol. 4, No. 1

** Due to the wording of this question, the survey marginals used for this item were for the response "generally underestimated" to get a positive measure of concern 


\section{Macrothink}

Environmental Management and Sustainable Development ISSN 2164-7682

Table S2. Distribution of Surveys including climate change concern questions used in the PCCTI and ICCTI

\begin{tabular}{|c|c|c|c|c|}
\hline & \multicolumn{2}{|c|}{ PCCTI } & \multicolumn{2}{c|}{ ICCTI } \\
\hline YEAR & Number of Surveys & Number of Questions & Number of Surveys & Number of Questions \\
\hline 2001 & 3 & 6 & 3 & 6 \\
\hline 2002 & 2 & 5 & 2 & 5 \\
\hline 2003 & 2 & 4 & 2 & 4 \\
\hline 2004 & 1 & 3 & 1 & 3 \\
\hline 2005 & 3 & 5 & 3 & 8 \\
\hline 2006 & 9 & 11 & 7 & 11 \\
\hline 2007 & 10 & 12 & 9 & 14 \\
\hline 2008 & 8 & 14 & 8 & 9 \\
\hline 2009 & 6 & 9 & 6 & 10 \\
\hline 2010 & 8 & 9 & 8 & 9 \\
\hline 2011 & 6 & 10 & 6 & 11 \\
\hline 2012 & 5 & 9 & 5 & 5 \\
\hline 2013 & 5 & 11 & 65 & \\
\hline Total & 69 & 108 & & \\
\hline
\end{tabular}

Table S3. Variable Loadings and Descriptive Statistics

\begin{tabular}{|c|c|c|c|c|}
\hline Variable & Cases & Dim 1 Loading & Mean & Std. Deviation \\
\hline Q12 & 13 & .961 & 31.538 & 4.466 \\
\hline Q13 & 2 & -1.000 & 36.000 & 3.000 \\
\hline Q2 & 2 & 1.000 & 35.500 & 5.500 \\
\hline Q34 & 4 & .984 & 65.500 & 4.031 \\
\hline Q35 & 10 & .624 & 42.941 & 7.793 \\
\hline Q38 & 8 & .563 & 35.125 & 3.018 \\
\hline Q46 & 2 & 1.000 & 49.000 & 3.000 \\
\hline Q47A & 2 & 1.000 & 64.500 & 5.500 \\
\hline Q53 & 11 & .875 & 40.000 & 4.954 \\
\hline
\end{tabular}


2015, Vol. 4, No. 1

\begin{tabular}{|c|c|c|c|c|}
\hline Q58 & 2 & 1.000 & 39.000 & 1.000 \\
\hline Q64 & 13 & .164 & 31.769 & 3.285 \\
\hline Q71 & 13 & .893 & 53.769 & 3.445 \\
\hline Q99 & 8 & .879 & 42.375 & 3.672 \\
\hline Q999 & 2 & 1.000 & 42.500 & 3.500 \\
\hline Q30 & 7 & -.500 & 30.000 & 4.440 \\
\hline Q32 & 2 & -1.000 & 44.500 & .500 \\
\hline Q33E & 5 & .922 & 38.400 & 5.200 \\
\hline Q63 & 3 & .679 & 63.000 & 3.742 \\
\hline QYM1 & 8 & .798 & 54.375 & 3.967 \\
\hline QYM2 & 8 & .338 & 33.750 & 4.841 \\
\hline
\end{tabular} \begin{tabular}{l} 
Dimension 1 Information \\
Eigen Estimate 1.44 of possible 2.4 \\
Pct Variance Explained: 60.04 \\
\hline
\end{tabular}

